\title{
Transferability of heterologous microsatellite primers in Leiarius marmoratus
}

\section{Transferibilidade de primers microssatélites heterólogos em Leiarius marmoratus}

\author{
Victor César Freitas Pandolfi ${ }^{1}$; Andrei Lincoln Yamachita ${ }^{1}$; Felipe Pinheiro de \\ Souza $^{1}$; Ed Christian Suzuki de Lima ${ }^{1}$; Denise Rocha Ayres ${ }^{2}$; Annaiza Braga \\ Bignardi²; Jayme Aparecido Povh ${ }^{3}$; Ulisses de Pádua Pereira ${ }^{4}$; Angela Maria Urrea- \\ Rojas $^{1}$; Nelson Mauricio Lopera-Barrero ${ }^{5 *}$
}

\section{Highlights:}

Genetic evaluation of Jundiá (Leiarius marmoratus) is limited due to the lack of specific microsatellite molecular markers.

Thirty-two heterologous primers were tested in L. marmoratus.

Four heterologous primers demonstrated satisfactory transferability patterns.

The use of the loci validated by the present study may be useful in genetic studies of this species.

\begin{abstract}
The Amazonian Jundiá (Leiarius marmoratus) (Siluliformes: Pimelodidae) is a species of catfish with social and economic importance in some South American countries such as Brazil and Colombia. Genetic evaluation of this species is limited due to the lack of specific molecular markers, hindering studies on genetic diversity and structure in animals under captive conditions or in natural populations. The objective of the present study was to evaluate the transferability of heterologous microsatellite markers in Leiarius marmoratus. Thirty-two heterologous primers were tested in L. marmoratus. The primers that presented the best standards were applied to 20 specimens, and the number of alleles (Na), number of effective alleles $(\mathrm{Ne})$, gene diversity per Locus $(\mathrm{GdL})$ and percentage of amplification failure (Md) were calculated. Eleven primers demonstrated satisfactory transferability patterns, all from the fish of the Pimelodidae family, of which, seven were monomorphic and four polymorphic. The eleven markers presented low percentage of Md (mean was 5.9\% samples per locus). Na varied from one to two alleles per locus, revealing low polymorphism in the evaluated samples. The mean $\mathrm{Ne}$ and GdL numbers were 1.77 and 0.32 , respectively. The transferability of the heterologous microsatellite loci in L. marmoratus was shown to be possible. However, further tests are needed to apply these markers in population genetic studies.
\end{abstract}

Key words: Aquaculture. Amazonian Jundiá. Cross-amplification. Genetic conservation. SSR.

\footnotetext{
1 Discentes do Programa de Pós-Graduação em Ciência Animal da Universidade Estadual de Londrina, UEL, Londrina, PR, Brasil. E-mail: vcfpand@gmail.com; andreilincoln16@gmail.com; felipeps1991@gmail.com; edchris7@hotmail.com; amur03013@ gmail.com;nmlopera@uel.br

2 Prof $^{\text {as }} \mathrm{Dr}^{\text {as }}$, Instituto de Ciências Agrárias e Tecnológicas, Universidade Federal de Mato Grosso, UFMT, Rondonópolis, MT, Brasil..E-mail: derocay@gmail.com; annaizabb@gmail.com

3 Prof. Dr., Faculdade de Medicina Veterinária e Zootecnia, Universidade Federal de Mato Grosso do Sul, UFMS, Campo Grande, MS, Brasil. E-mail: jayme.povh@ufms.br

4 Prof. Dr., Departamento de Medicina Veterinária Preventiva, Programa de Pós-Graduação em Ciência Animal, UEL, Londrina, PR, Brasil. E-mail: upaduapereira@uel.br

5 Prof. Dr., Departamento de Zootecnia, Programa de Pós-Graduação em Ciência Animal, UEL, Londrina, PR, Brasil. E-mail: nmlopera@uel.br

* Author for correspondence
} 


\section{Resumo:}

O Jundiá da Amazônia (Leiarius marmoratus) (Siluliformes: Pimelodidae) é uma espécie de catfish com importância social e econômica em alguns países Sul americanos como Brasil e Colômbia. A avaliação genética dessa espécie é limitada devido a ausência de marcadores moleculares específicos para $L$. marmoratus, dificultando estudos sobre a diversidade e estrutura genética em animais em condições de cativeiro ou em populações naturais. O objetivo do presente estudo foi avaliar a transferibilidade de 32 marcadores microssatélites heterólogos em Leiarius marmoratus. Os primers que apresentaram melhores padrões foram aplicados em 20 espécimes, sendo calculados o número de alelos (Na), número de alelos efetivos $(\mathrm{Ne})$, diversidade gênica por Locus $(\mathrm{GdL})$ e porcentagem de falha na amplificação (Md). Onze primers demonstraram padrões satisfatórios de transferibilidade, todos oriundos de peixes da família Pimelodidae, dos quais sete foram monomórficos e quatro polimórficos. Os onze marcadores apresentaram baixa porcentagem de Md (média 5,9\% amostras por loco). O Na variou de um a dois alelos por loco, revelando baixo polimorfismo nas amostras avaliadas. O número médio de $\mathrm{Ne}$ e GdL foram 1,77 e 0,32, respectivamente. Estudos genéticos envolvendo indivíduos de diferentes regiões poderão apresentar novos alelos e maior número de loci polimórficos. A transferibilidade de loci microssatélites heterólogos em L. marmoratus se mostrou possível, no entanto, novos testes são necessários para aplicação desses marcadores em estudos genéticos populacionais.

Palavras-chave: Aquicultura. Amplificação cruzada. Conservação genética. Jundiá amazônico. SSR.

\section{Introduction}

Currently, aquaculture has consolidated as an important activity for the production of protein from animal origin. According to the Food and Agriculture Organization [FAO] (2018), aquaculture production in 2016 reached a total of 80 million tonnes, of a total of 170.9 million tonnes, when also considering capture. One of the South American species with potential for cultivation is the Amazonian Jundiá (Leiarius marmoratus), a species distributed in the Amazon, Essequibo, and Orinoco Rivers (Ramírez-Gil \& Ajiaco-Martínez, 1997). The fact that it is omnivorous and is used to produce hybrids with females of Pseudoplatystoma spp., makes the production of this species relevant in South American countries such as Brazil and Colombia (Cruz-Casallas, Marciales-Caro, DíazOlarte, \& Cruz-Casallas, 2010; Lopera-Barrero Ribeiro, Povh, Mendes, \& Poveda-Parra, 2011; Araújo et al., 2014).

For captive production, one important characteristic to be considered is genetic diversity, since it guarantees adaptation to the environmental variation present in the farming environment (Petersen et al., 2012). Among the tools successfully used in genetic studies, microsatellites stand out as molecular markers used to analyze diversity and population structure. They are codominant markers, show high levels of variability, high processing speed, cover the genome uniformly, and allow the isolation of a high number of loci (AbdulMuneer, 2014). However, as these markers require information from the genome, their use is limited to species without specific primers, with one of the solutions being the use of heterologous primers, in other words, molecular markers of other species (Castro et al., 2017). In general, primers of species with phylogenetic proximity are used, and generally the primers with the highest reproducibility are those from species belonging to the same genus or family (Carmo, Polo, Silva, \& Yazbeck., 2015; Castro et al., 2017; Lima et al., 2008).

Some studies have demonstrated the efficiency of cross-amplification in Brazilian native fish species, such as Brycon orbignyanus (Carmo et al., 2015), Brycon gouldingi (Souza et al., 2018a), Leporinus elongatus, Rhamdia quelen (Lopera-Barrero et al., 2016), and Colossoma macropomum (Lima et al., 2008). However, the lack of characterization of specific molecular markers 
or studies with transferability of microsatellite primers in L. marmoratus limits genetic studies on this species. Studies that evaluated the transfer of primers in species of the family Pimelodidae, the same family as L. marmoratus, found that crossamplification is possible between members of this family. Saulo-Machado et al. (2011) observed that specific primers of Pseudoplatystoma punctifer were successful in transferability in six different species of this family (Pseudoplatystoma tigrinum, $P$. reticulatum, $P$. magdaleniatum, $P$. corruscans, Brachyplatystoma juruense, and B. platinemum). In another study, it was possible to observe the crossamplification of specific $P$. corruscans primers in four species of the same family (Pseudoplatystoma fasciatum, Steindachneridion scripta, Pirinampus pirinampu, and Pimelodus maculatus) (Revaldaves, Pereira, Foresti, \& Oliveira, 2005). In addition, the authors found the possibility of transferring these markers to species from other families, such as members of the Cetopsidae and Loricariidae family, although with less polymorphism. In view of these results, it is likely that the cross-amplification of microsatellite primers developed for species of the family Pimelodidae is possible and applicable in $L$. marmoratus. The possibility of transferring markers from other genera and classes to this species is also noted.

Therefore, the objective of the present work was to evaluate the transferability of microsatellite markers of nine species of fish (Pseudoplatystoma punctifer, Colossoma macropomum, Brycon hilarii, Brachyplatystoma rousseauxii, Brycon orbignyanus, Piaractus mesopotamicus, Prochilodus argenteus, Brycon opalinus, and Pseudoplatystoma corruscan) in Leiarius marmoratus.

\section{Materials and Methods}

Caudal fin fragments (approximately 0.5 $\mathrm{cm}^{2}$ ) were collected from Leiarius marmoratus specimens, sampled at a fish farm located in the municipality of Nova Mutum (Mato Grosso, MT, Brazil). The samples were inserted into microtubes containing $70 \%$ alcohol until transport to the Laboratory of the "Núcleo de Estudo e Pesquisa em Aquicultura e Genética (NEPAG)," of the State University of Londrina (UEL).

For extraction of fin DNA, the $\mathrm{NaCl}$ protocol described by Lopera-Barrero et al. (2008) was used. The DNA concentration was measured with the use of the SLIPQ 026-Quantifier L-Quant spectrophotometer (Loccus Biotecnology, Ribeirão Preto, Brazil) and the samples were diluted to a final volume of $30 \mathrm{ng} \mu \mathrm{L}^{-1}$. DNA integrity was checked on $1 \%$ agarose gel stained with SYBR Safe ${ }^{\text {TM }}$ DNA (Invitrogen), and electrophoresis was performed in $1 \mathrm{X}$ TBE buffer for $60 \mathrm{~min}$ at $100 \mathrm{~V}$. The gel was observed with the aid of a UV trans-illuminator and the image was captured by the photo-documentation system.

For the cross-amplification tests, 32 microsatellite primers were used in five Leiarius marmoratus specimens, of which six primers belonged to the species Pseudoplatystoma punctifer: PPU1, PPU2, PPU4, PPU10, PPU13, PPU15 (Saulo-Machado et al., 2011); four primers described for Colossoma macropomum: Cm1A8, Cm1A11, Cm1D1, and Cm1E3 (Santos, Hrbek, \& Farias, 2009); three described for Brycon hilarii: Bh6, Bh8, and Bh16 (Sanches \& Galetti, 2006); four for Brachyplatystoma rousseauxii: BR38, BR47, BR51, and BR61 (Batista, 2010); three described for Brycon orbignyanus: Borg9, Borg13, and Borg4 (Souza et al., 2018b); four for Piaractus mesopotamicus: PME2, PME4, PME21 and PME32 (Calcagnotto, Russello, \& DeSalle, 2001); two for Prochilodus argenteus: Par15 and Par21 (Barbosa, Correa, Galzerani, Galetti, \& Hatanaka, 2006); two for Brycon opalinus: BoM5 and BoM13 (Barroso et al., 2003); and four primers described for Pseudoplatystoma corruscans: Pcor1, Pcor5, Pcor8, and Pcor10 (Revaldaves, Pereira, Foresti, \& Oliveira, 2005). 
Amplification was performed for a final reaction volume of $15 \mu \mathrm{l}$ using $1 \mathrm{X}$ of Tris-KCl buffer, 1.75 and $2.0 \mathrm{mM} \mathrm{MgCl} 2$ (the two concentrations of this reagent were tested for each primer), $0.4 \mu \mathrm{M}$ of each primer (Forward and Reverse), $0.2 \mathrm{mM}$ of each dNTP, one unit of Platinum Taq DNA Polymerase and $45 \mathrm{ng}$ of DNA. Initially, DNA was denatured at $94{ }^{\circ} \mathrm{C}$ for $4 \mathrm{~min}$ followed by 30 cycles of $40 \mathrm{~s}$ of initial denaturation at $94{ }^{\circ} \mathrm{C}, 45 \mathrm{~s}$ of annealing (varying temperature for each primer), and $60 \mathrm{~s}$ of extension at $72{ }^{\circ} \mathrm{C}$. Lastly, a final extension was carried out at $72{ }^{\circ} \mathrm{C}$ for $10 \mathrm{~min}$. The annealing temperatures of the microsatellite markers were followed according to each author.

The amplified samples were submitted to electrophoresis on $10 \%$ polyacrylamide gel, conducted in $0.5 \mathrm{X}$ TBE buffer with $180 \mathrm{~V}$ and 250 $\mathrm{mA}$ for $450 \mathrm{~min}$. Subsequently, nitrate staining was performed to visualize the alleles. The gel was photo-documented and submitted to the Adobe Photoshop CC software (64 Bit), where it was aligned and the alleles were calculated using 100 bp DNA ladder. The primers that presented satisfactory amplification patterns were selected for the population analysis. For this, 20 individuals were genotyped to calculate the genetic indexes. All other loci selected showed better resolution with $\mathrm{MgCl}_{2}$ at $2 \mathrm{mM}$ concentration, except for the Pcor1 and Pcor5 loci. For these, the concentration of 1.75 $\mathrm{mM}$ was standardized for population analysis.

The number of alleles $(\mathrm{Na})$ and effective number of alleles $(\mathrm{Ne})$ were calculated for each locus using GenAlex version 6.5 software (Peakall \& Smouse, 2012). Genetic diversity by locus (Nei, 1978) was calculated using the FSTAT 2.9.3 software (Goudet, 2001). The presence of null alleles was tested using the Micro-Checker version 2.2.3 software (Van Oosterhout, Hutchinson, Wills, \& Shipley, 2004).

\section{Results and Discussion}

Overall, 11 primers were obtained after exclusion of the primers showing non-specific patterns or absence of amplification, which demonstrated adequate transferability patterns. Of these primers, seven were monomorphic (from P. punctifer - PPU1, PPU2, PPU9, PPU10, and PPU13 and B. rousseauxii - BR51 and BR61) and four polymorphic (from $B$. rousseauxii - BR38 and BR47 and P. corruscans Pcor1 and Pcor5).

When evaluating amplification, on average only $5.9 \%$ of the samples per locus showed defects in the PCR, represented by the absence of bands in the gel. The number of alleles produced ranged from one (PPU1, PPU9, and PPU13) to two (PPU2, PPU10, BR35, BR47, BR51, BR61, Pcor1, and Pcor5) per loci. The detailed characterization of the 11 loci used, the allele sizes (base pairs - bp) in the present study, and the allele sizes found in studies with allele numbers $(\mathrm{Na})$, number of effective alleles $(\mathrm{Ne})$, gene diversity per locus (GdL), and percentage of amplification failure (Md) are presented in Table 1. The presence of null alleles ( $p<0.05$ ) was detected only at the BR38 locus.

The cross-amplification of microsatellite markers depends on the conservation of the regions that flank the short sequence repeats (SSR), and the success of the amplification is related to the evolutionary distance of the species (Oliveira, Pádua, Zucchi, Vencovsky, \& Vieira, 2006). This is reinforced by recent studies that demonstrated that the transferability of microsatellite primers is more satisfactory among different species within the same genus, although amplification between distinct genus or family is also possible (Castro et al., 2017; Revaldaves et al., 2005; Souza et al., 2018a), including different families of the order Siluliformes 
(Revaldaves et al., 2005), but none that covers the genus Leporinus. With a distribution of 478 genera and 36 families, the order Siluriformes is the second largest in the neotropical regions with most of the species found in the Pantanal region (Carvalho Lima, Egito, Feijó, Arruda Mauro, \& Ferraz, 2017; Ferraris, 2007). A study with DNA barcoding with 15 species belonging to 12 genera and 5 families of that order in the Paraguay River basin showed that eight species (53\%) showed similarity above 99\%, with an average genetic distance of $0.2 \%$ between species, $1.6 \%$ between genders and $4.2 \%$ between families (Carvalho Lima et al., 2017). Corroborating the genetic similarity of members of that order, the loci tested in the present study demonstrated that only those from fish of the family Pimelodidae were successful in the amplification.

The absence of specific primers described for the genus Leiarius hinders the transferability test, which requires evaluations with markers of the same family (Pimelodidae), such as those described for P. punctifer, P. corruscans, and B. rousseauxi, which could have caused low polymorphism in L. marmoratus samples. Another reason may be due to the low number of samples and absence of individuals from other regions. It is believed that future studies involving individuals from different fish farms and/or river basins may present new alleles and a greater number of polymorphic loci.
Genetic studies have recently shown that heterologous microsatellite markers are able to differentiate hybrid species from pure species as assessed by Parveen, Abbas, Afzal \& Hussain (2018) in a study with three species of carp (Labeo rohita, Catla catla, and Cirrhinus mrigala) and EsquerGarrigos et al. (2015) in Andean pupfishes (Orestias agassizii and $O$. luteus). This is very important when dealing with species of the Pimelodidae family, since the intergenic hybridization of catfish, including $L$. marmoratus and $P$. reticulatum, is common in South American fish farms (Hashimoto, Prado, Foresti \& Porto-Foresti, 2016), and may present risks of genetic contamination of natural stocks by accidental releases, leading to genetic introgression (Hashimoto, Senhorini, Foresti, Martínez, \& PortoForesti, 2014).

The results of the present study demonstrate difficulty in obtaining polymorphism in the markers evaluated for L. marmoratus. This fact reinforces the importance of the development and characterization of microsatellite primers specific to the species. Alternatively, new tests can be carried out in order to validate heterologous microsatellite primers for population genetic studies in L. marmoratus. It is believed that the use of microsatellites developed for related species such as $P$. reticulatum (Prado et al., 2014) and Rhamdia quelen (Rodrigues et al., 2015) can increase the number of microsatellite markers useful for such analyses. 


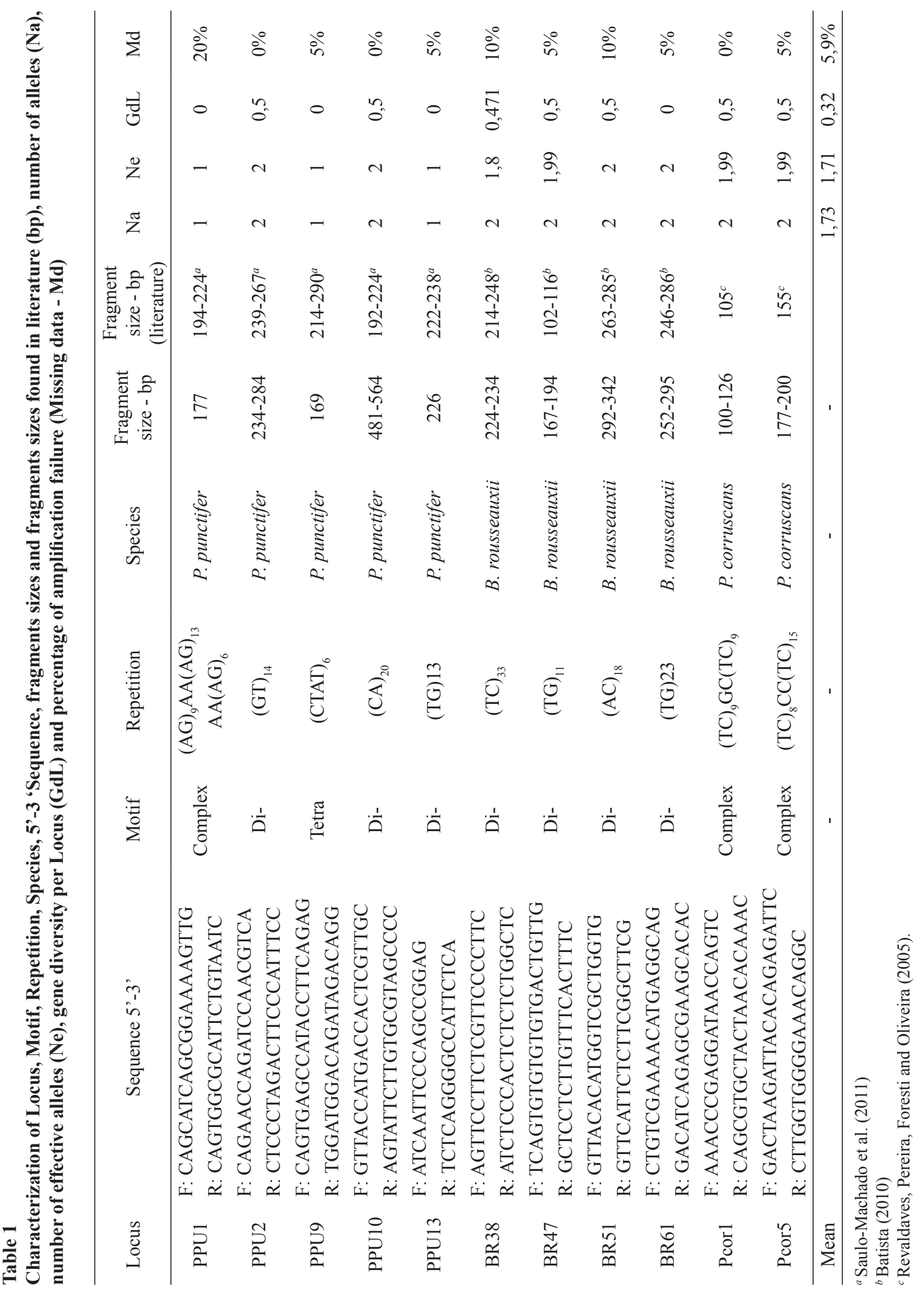




\section{Acknowledgments}

The authors would like to thank the CNPq, CAPES and the 'Programa de Pós Graduação em Ciência Animal' (State University of Londrina).

\section{References}

Abdul-Muneer, P. M. (2014). Application of microsatellite markers in conservation genetics and fisheries management: recent advances in population structure analysis and conservation strategies. Genetics Research International, 2014(ID 691759), 1-11. doi: 10.1155/2014/691759

Araújo, J. E. X. S., Streit, D. P, Jr., Ribeiro, J. S. A., Martins, E. F. F., Souza, F. N., Oliveira, C. A. L.,... Povh, J. A. (2014). Ovopel and carp pituitary extract as spawning inducers in males of the Amazon Catfish Leiarius marmoratus (Gill, 1970). Brazilian Archives of Biology and Technology, 7(6), 882-886. doi: 10.1590/S1516-8913201402469

Barbosa, A. C. D. R., Correa, T. C., Galzerani, F., Galetti, P. M., \& Hatanaka, T. (2006). Thirteen polymorphic microsatellite loci in the Neotropical fish Prochilodus argenteus (Characiformes, Prochilodontidae). Molecular Ecology Notes, 6(3), 936-938. doi: 10.1111/j.1471-8286.2006.01406.x

Barroso, R. M., Hilsdorf, A. W. S., Moreira, H. L. M., Mello, A. M., Guimarães, S. E. F., Cabello, P. H., \& Traub-Cseko, M. (2003). Identification and characterization of microsatellites loci in Brycon opalinus (Cuvier, 1819) (Characiforme, Characidae, Bryconiae). Molecular Ecology Notes, 3(2), 297298. doi: 10.1046/j.1471-8286.2003.00435.x

Batista, J. S. (2010). Caracterização genética da dourada-Brachyplatystoma rousseauxii, Castelnau, 1855 (Siluriformes: Pimelodidae) na Amazônia por meio de marcadores moleculares mitocondriais e microssatélites: subsídios para conservação e manejo. Manaus: Instituto Nacional de Pesquisas da Amazônia 2010. Recuperado de https://bdtd.inpa. gov.br/handle/tede/721

Calcagnotto, D., Russello, M., \& DeSalle, R. (2001). Isolation and characterization of microsatellite loci in Piaractus mesopotamicus and their applicability in other Serrasalminae fish. Molecular Ecology Notes, 1(4), 245-247. doi: 10.1046/j.14718278.2001.00091.x

Carmo, F. M. S., Polo, É. M., Silva, M. A., \& Yazbeck, G. M. (2015). Optimization of heterologous microsatellites in Piracanjuba. Pesquisa Agropecuária Brasileira, 50(12), 1236-1239. doi: 10.1590/ S0100-204X2015001200015

Carvalho Lima, T. P., Egito, A. A., Feijó, G. L. D., Arruda Mauro, R., \& Ferraz, A. L. J. (2017). Molecular identification and phylogenetic analysis of Siluriformes from the Paraguay River basin, Brazil. Mitochondrial DNA Part A, 28(4), 536-543. doi: $10.3109 / 24701394.2016 .1149825$

Castro, P. L., Ribeiro, R. P., Santos, S. C. A., Goes, E. S. R., Souza, F. P., Poveda-Parra, A. R., Lopera-Barrero, N. M. (2017). Cross-amplification of heterologous microsatellite markers in Piracanjuba. Ciência Rural, 47(12), 1-6. doi: 10.1590/0103-8478cr20170374

Cruz-Casallas, N. E., Marciales-Caro, L., Díaz-Olarte, J. J., \& Cruz-Casallas, P. E. (2010). Desempeño productivo del yaque (Leiarius marmoratus Gill, 1870) bajo diferentes densidades de siembra en estanques en tierra. Revista Colombiana de Ciencias Pecuárias, 23(3), 325-335.

Esquer-Garrigos, Y., Hugueny, B., Ibañez, C., Zepita, C., Koerner, K., Lambourdière, J., Couloux A., \& Gaubert, P. (2015). Detecting natural hybridization between two vulnerable Andean pupfishes (Orestias agassizii and $O$. luteus) representative of the Altiplano endemic fisheries. Conservation Genetics, 16(3), 717-727. doi: 10.1007/s10592-015-0695-3

Ferraris, C. J. (2007). Checklist of catfishes, recent and fossil (Osteichthyes: Siluriformes), and catalogue of siluriform primary types. Zootaxa, 1418(1), 1-628. doi: 10.11646/zootaxa.1418.1.1

Food and Agriculture Organization (2018). The State of World Fisheries and Aquaculture 2018 - Meeting the sustainable development goals (Vol. 35). Rome: FAO.

Goudet, J. (2001). FSTAT: A program to estimate and test gene diversities and fixation indices (version 2.9.3.2). Retrieved from https://www.scienceopen. com/document?vid=79097bb4-ec3c-47c3-94a1$47085 \mathrm{~d} 721 \mathrm{e} 6 \mathrm{~b}$

Hashimoto, D. T., Prado, F. D., Foresti, F., \& PortoForesti, F. (2016). Molecular identification of intergenus crosses involving catfish hybrids: risks for aquaculture production. Neotropical Ichthyology, 14(2), 1-8. doi: 10.1590/1982-0224-20150139

Hashimoto, D. T., Senhorini, J. A., Foresti, F., Martínez, P., \& Porto-Foresti, F. (2014). Genetic identification of $\mathrm{F} 1$ and Post-F1 serrasalmid juvenile hybrids in brazilian aquaculture. PLoS One, 9(3), 1-8. doi: 10.1371/journal.pone.0089902 
Lima, J. S., Telles, M. P. C., Resende, L. V., Gouveia, F. O., Boni, T. A., \& Sanches, A. C. (2008). Amplificação cruzada e padronização de marcadores microssatélites em Colossoma macropomum (tambaqui). Revista de Biologia Neotropical, 5(2), 41-49. doi: 10.5216/rbn.v5i2.9821

Lopera-Barrero, N. M., Ribeiro, R. P., Povh, J. A., Mendes, L. D. V. \& Poveda-Parra, A. R. (2011). Produção de organismos aquáticos: Uma visão geral do Brasil e no Mundo. Guaíba, RS: Editora Agrolivros.

Lopera-Barrero, N. M., Povh, J. A., Ribeiro, R, P., Gomes, P. C., Jacometo, C. B., \& Lopes, T. S. (2008). Comparación de protocolos de extracción de ADN con muestras de aleta y larva de peces: extracción modificada con cloruro de sodio. Ciencia e Investigación Agraria, 35(1), 15-24. doi: 10.4067/ S0718-16202008000100008

Lopera-Barrero, N. M., Tanamati, F., RodriguezRodriguez, M. P., Povh, J. A., Poveda-Parra, A. R., Otonel, R. A. A.,... Ribeiro, R. P. (2016). Crossamplification of heterologous microsatellite markers in Rhamdia quelen and Leporinus elongatus. Semina: Ciências Agrarias, 37(1), 517-524. doi: 10.5433/ 1679-0359.2016v37n1p517

Nei, M. (1978). Estimation of average heterozygosity and genetic distance from a small number of individuals. Genetics, 89(3), 583-590.

Oliveira, E. J., Pádua, J. G., Zucchi, M. I., Vencovsky, R., \& Vieira, M. L. C. (2006). Origin, evolution and genome distribution of microsatellites. Genetics and Molecular Biology, 29(2), 294-307. doi: 10.1590/ S1415-47572006000200018

Parveen, S., Abbas, K., Afzal, M., \& Hussain, M. (2018). Prediction of potential hybridization between three major carps in ravi river (Punjab, Pakistan) basin by using microsatellite markers. Turkish Journal of Fisheries and Aquatic Sciences, 18(1), 27-35. doi: 10.4194/1303-2712-v18_1_04.

Peakall, R., \& Smouse, P. E. (2012). GenAlEx 6.5: genetic analysis in Excel. Population genetic software for teaching and research--an update. Bioinformatics, 28(19), 2537-2539. doi: 10.1093/bioinformatics/bts 460

Petersen, R. L., Garcia, J. E., Mello, G., Liedke, A. M. R., Sincero, T. C. M., \& Grisard, E. C. (2012). Análise da diversidade genética de tilápias cultivadas no estado de Santa Catarina (Brasil) utilizando marcadores microssatélites. Boletim do Instituto de Pesca, 38(4), 313-321.
Prado, F. D., Pardo, B. G., Guerra-Varela, J., Senhorini, J. A., Martínez, P., Foresti, F., \& Porto-Foresti, F. (2014). Development and characterization of 16 microsatellites for the Neotropical catfish Pseudoplatystoma reticulatum and cross species analysis. Conservation Genetics Resources, 6(3), 679-681. doi: 10.1007/s12686-014-0180-1

Ramírez-Gil, H., \& Ajiaco-Martínez, R. (1997). Aspectos preliminares de la biologia pesquera del Yaque, Leiarius marmoratus (Guii, 1870) (pisces: siluriformes: pimelodidae) en la parte alta del rio Meta (Orinoquia colombiana). Boletín Científico INPA 1997. Recuperado de https:/www.worldcat. org/title/aspectos-preliminares-de-la-biologiapesquera-del-yaque-leiarius-marmoratus-guii-1870pisces-siluriformes-pimelodidae-en-la-parte-altadel-rio-meta-orinoquia-colombiana/oclc/819847273

Revaldaves, E., Pereira, L. H. G., Foresti, F., \& Oliveira, C. (2005). Isolation and characterization of microsatellite loci in Pseudoplatystoma corruscans (Siluriformes: Pimelodidae) and cross-species amplification. Molecular Ecology Notes, 5(3), 463465. doi: 10.1111/j.1471-8286.2005.00883.x

Rodrigues, M. D. N., Moreira, C. G. A., Gutierrez, H. J. P., Almeida, D. B., Junoir, D. S., \& Moreira, H. L. M. (2015). Development of microsatellite markers for use in breeding catfish, Rhamdia sp. African Journal of Biotechnology, 14(5), 400-411. doi: 10.5897/ AJB2014.14116

Sanches, A., \& Galetti, P. M. (2006). Microsatellites loci isolated in the freshwater fish Brycon hilarii. Molecular Ecology Notes, 6(4), 1045-1046. doi: 10.1111/j.1471-8286.2006.01427.x

Santos, M. D. C. F., Hrbek, T., \& Farias, I. P. (2009). Microsatellite markers for the tambaqui (Colossoma macropomum, Serrasalmidae, Characiformes), an economically important keystone species of the Amazon River floodplain. Molecular Ecology Resources, 9(3), 874-876. doi: 10.1111/j.1755-0998. 2008.02331.x

Saulo-Machado, A. C., Formiga, K. M., Ortiz, M. F., Sousa, A. C. B., Alves-Gomes, J. A., \& Batista, J. S. (2011). Polymorphic microsatellite DNA markers for the Amazonian catfish Pseudoplatystoma punctifer (Siluriformes: Pimelodidae). Conservation Genetics Resources, 3(2), 307-310. doi: 10.1007/ s12686-0109349-4

Souza, F. P., Lima, E. C. S., Leite, N. G., Urrea-Rojas, A. M., Yamachita, A. L., Pandolfi, V. C. F., \& Lopera-Barrero, N. M. (2018a). Transferability 
of heterologous microsatellite primers in Brycon gouldingi. Ciência Rural, 48(11), 1-6. doi: 10.1590/0103-8478cr20180412

Souza, F. P., Urrea-Rojas, A. M., Ruas, C. F., Povh, J. A., Ribeiro, R. P., Ruas, E. A.,... Lopera-Barrero, N. M. (2018b). Novel microsatellite markers for the endangered neotropical fish Brycon orbignyanus and cross-amplification in related species. Italian
Journal of Animal Science, 17(4), 916-920. doi: 10.1080/ 1828051X.2018.1436008

Van Oosterhout, C., Hutchinson, W. F., Wills, D. P., \& Shipley, P. (2004). MICRO CHECKER: software for identifying and correcting genotyping errors in microsatellite data. Molecular Ecology Notes, 4(3), 535-538. doi: 10.1111/j.1471-8286.2004.00684.x 
